\title{
PREVALENSI CACING PARASITIK PADA ANAK SEKOLAH DASAR DI KECAMATAN RAKUMPIT KOTA PALANGKA RAYA
}

\author{
Ashari Mohpul ${ }^{1 a^{*}}$, Arif Rahman Jabal ${ }^{2 b^{*}}$, Abi Bakring Balyas ${ }^{3 c}$ \\ ${ }_{1}^{1}$ Pendidikan Kedokteran, Fakultas Kedokteran, Universitas Palangka Raya, Indonesia \\ ${ }^{2}$ Departemen Parasitologi, Fakultas Kedokteran, Universitas Palangka Raya, Indonesia \\ ${ }^{3}$ Departemen Fisiologi, Fakultas Kedokteran, Universitas Palangka Raya, Indonesia \\ Email: arifrjabal@med.upr.ac.id
}

\begin{abstract}
Infeksi cacing parasit dapat mempengaruhi konsentrasi siswa sekolah dasar dalam menerima pelajaran di sekolah. Tujuan penelitian ini untuk mengetahui prevalensi cacing parasit yang menginfeksi anak Sekolah Dasar di Kecamatan Rakumpit. Pemeriksaan keberadaan telur cacing meliputi memberikan kuisioner, pengambilan sampel feses, pengerjaan feses menggunakan metode Kato- Katz, identifikasi telur cacing. Hasil penelitian ini yaitu karakteristik anak SD yang tertinggi yaitu tidak memakai alas kaki saat bermain. Distribusi spesies cacing parasit yang ditemukan yaitu Ascaris lumbricoides, Toxocara sp., Taenia sp., dan Fasciolopsis sp. Prevalensi cacing parasitik tertinggi yaitu Ascaris lumbricoides sebesar 69,38\%. Intensitas cacing paling banyak ditemukan yaitu Ascaris lumbricoides sebesar 83\%. Anak Sekolah Dasar tidak memakai alas kaki pada saat bermain erat kaitannya dengan prevalensi dan intensitas cacing di Kecamatan Rakumpit.
\end{abstract}

Kata Kunci: Anak sekolah dasar, cacing parasitic, prevalensi

\section{PENDAHULUAN}

Kecamatan Rakumpit bagian dari salah satu kecamatan di Kota Palangka Raya. Berdasarkan posisi geografisnya kecamatan tersebut berbatasan Kabupaten Gunung Mas di sebelah utara, Kecamatan Bukit Batu di sebelah selatan, Kabupaten Katingan di sebelah barat dan Kabupaten Pulang pisau di sebelah timur. Wilayah Kota Palangka Raya terbagi atas tiga wilayah, yaitu perkotaan, pedesaan dan hutan[1]. Kecamatan rakumpit masih tergolong pedesaan dan hutan. Kasus kecacingan cukup tinggi di daerah pedesaan[2]. Kasus kecacingan pada anak sekolah dasar cukup tinggi di pedesaan[3].

Usia anak sekolah dasar sering terinfeksi kecacingan karena sering kontak tanah[4]. Manifestasi penyakit kecacingan pada anak-anak tergantung pada perkembangan parasit dan intensitas infeksi. Cacing dewasa dapat bertahan hidup di saluran pencernaan *Corresponding Author :

\section{Arif Rahman Jabal}

Departemen Parasitologi, Fakultas Kedokteran

Universitas Palangka Raya, Indonesia

Email : arifrjabal@med.upr.ac.id selama sekitar 1 tahun. Infeksi saluran cerna yang berat dapat menyebabkan malabsorbsi, diare, anemia dan kekurangan gizi[5] Infeksi cacing pada anak-anak juga dapat mengganggu.

$$
\text { pertumbuhan }
$$

(pengerdilan), menyebabkan keterbelakangan intelektual atau mempengaruhi kemampuan kognitif dan pendidikan.

Prevalensi cacing parasit pada anakanak sebesar 57,6\%[6]. Anak-anak terinfeksi cacing parasit sebesar 26,5\%[7]. Prevalensi cacing parasit pada anak-anak sebesar 36\% [8]. Kecacingan salah satu penyakit anak di Indonesia dengan prevalensi sebesar 40,21\% [9]. Anak-anak yang terinfeksi cacingan sebesar $29,8 \%[10]$.

Spesies cacing yang ditemukan cacing Ascaris lumbricoides, hookworm, Trichuris 
trichiura, Enterobius vermucularis, dan Trichostrongylus orientalis [11]. Cacing parasit yang dapat ditemukan pada Anak Sekolah Dasar yaitu Ascaris lumricoides, Trichuris trihiura, Enterobius vermucularis

dan Hookworm [12]. Jenis cacing dapat ditemukan pada feses anak Sekolah Dasar Ascaris lumricoides, Trichuris trihiura, hookworm [13]. Penelitian mengenai prevalensi cacing parasitik pada anak Sekolah Dasar di

\section{METODE PENELITIAN}

Penelitian ini tergolong survei deskriptif dengan pendekatan Simple Random Sampling untuk mengetahui prevalensi cacing parasit pada anak SD di Kecamatan Rakumpit di Kota Palangka Raya. SDN Petut Bukit 1, SDN Petut Bukit 2, SDN Pager Jaya 1 menjadi sekolah pengambilan sampel. Penelitian ini dilaksanakan pada bulan Oktober-Desember 2019. Populasi pada penelitian yaitu seluruh siswa SD kelas 1 3. Jumlah sampel yang berhasil diambil sebanyak 49 pot sampel. Penelitian ini meliputi pengambilan sampel feses dan dibawa ke Laboratorium
Kecamatan Rakumpit belum ada data atau publikasi.
Biomedik Fakultas Kedokteran Universitas Palangka Raya. Pengerjaan sampel tersebut menggunakan teknik Kato-Katz. Pemeriksaan keberadaan telur cacing menggunakan mikroskop binokuler. Analis data dilakukan secara deskriptif.

\section{HASIL DAN PEMBAHASAN}

Karakteristik Anak Sekolah Dasar terkena kecacingan di Kecamatan Rakumpit

Tabel 1 Karakteristik responden kecacingan Siswa SD di Kecamatan Rakumpit

\begin{tabular}{clc}
\hline No & \multicolumn{1}{c}{ Karakteristik responden } & $\%$ \\
\hline 1 & Tidak cuci tangan sebelum makan & 28 \\
2 & Tidak pakai sabun setelah BAB & 22 \\
3 & Tidak pakai sabun setelah bermain Tanah & 22 \\
4 & Bermain tidak pakai alas kaki & 32 \\
5 & Kuku tidak Bersih & 16 \\
6 & Tidak tersedianya WC & 12 \\
\hline
\end{tabular}

\section{Distribusi Cacing Parasitik}

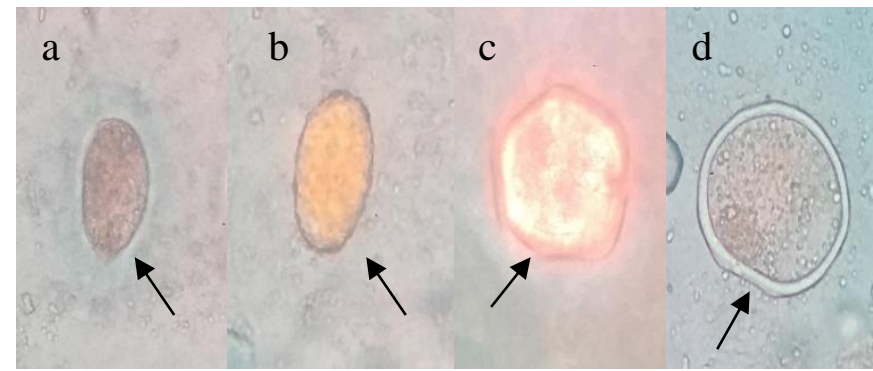

Gambar 1. Spesies cacing parasit pada perbesaran 400x. a. Fasciolopsis sp., b. Ascaris lumbricoides, c. Taenia sp., d. Toxocara sp. 
Tabel 2 Prevalensi cacing parasit pada anak Sekolah Dasar di Kecamatan Rakumpit

\begin{tabular}{lcccc}
\hline \multicolumn{1}{c}{ Spesies cacing } & $\begin{array}{c}\text { Sampel } \\
\text { Positif }\end{array}$ & Prevalensi & $\begin{array}{c}\text { Jumlah telur } \\
\text { cacing }\end{array}$ & Intensitas \\
\hline Ascaris lumricoides & 34 & $69,38 \%$ & 227 & $83 \%$ \\
Toxocara sp. & 4 & $8 \%$ & 42 & $15 \%$ \\
Taenia sp. & 1 & $2 \%$ & 2 & $0,7 \%$ \\
Fasciolopsis sp. & 4 & $8 \%$ & 3 & $1 \%$ \\
\hline
\end{tabular}

Anak Sekolah Dasar yang terinfestasi kecacingan sebesar $71 \%$ di kecamatan Rakumpit. Siswa laki-laki paling banyak terkena cacingan sebesar $74,2 \%$ dibandingkan siswa perempuan.

\section{Karakteristik Anak Sekolah Dasar terkena kecacingan di Kecamatan Rakumpit}

Pada tabel 1 menunjukkan bahwa siswa SD yang bermain tidak pakai alas kaki sebesar $(32 \%)$. Kasus kecacingan terjadi karena tidak memakai alas kaki sebesar $(1,38 \%)$ [14]. Anak yang tidak menggunakan alas kaki sebanyak (7,5\%) [15]. Tidak memakai alas kaki saat keluar rumah sebesar 45,2\% [16]. Hubungan antara penularan kecacingan dengan tidak memakai alas kaki erat kaitannya. Larva cacing parasit terdapat di tanah. Anak SD bisa terkena cacingan dengan cara bermain tidak memakai alas kaki, cacing tersebut dapat berpindah melalui pori-pori kulit kaki. Persentasi anak SD yang tidak cuci tangan sebelum makan sebesar (28\%). Sebelum makan tidak mencuci tangan rentan terinfeksi cacingan. Telur cacing yang berada di tanah bisa berpindah ke tangan, karena tidak cuci tangan sebelum makan, telur cacing dapat berpindah melalui mulut.

\section{Distribusi cacing parasitik}

Pada gambar 1 , jenis cacing parasit yang ditemukan pada sampel feses anak sekolah Dasar yaitu cacing Fasciolopsis sp., Ascaris lumbricoides, Taenia sp., Toxocara sp. Spesies cacing yang banyak ditemukan yaitu cacing Ascaris lumbricoides.

\section{Prevalensi cacing parasitik}

Pada tabel 2. menggambarkan prevalensi tertinggi yaitu cacing Ascaris lumbricoides sebesar (69,38\%). Derajat infeksi cacing Ascaris lumbricoides sebesar 36,5\% [17]. Prevalensi cacing tersebut sebesar (14,32\%) [18]. Cacing tersebut tergolong STH (soil transmitted helminths). Transmisi STH dapat terjadi melalui fekal-oral yang bersentuhan dengan tanah yang terdapat telur cacing parasit. Prevalensi cacing tersebut tinggi di Kecamatan Rakumpit dapat dipengaruhi dari kebiasaan buang besar di tanah, kotoran hewan peliharaan ditemukan di tanah menjadi faktor penentu penyebaran telur cacing A. lumbricoides ke anak SD yang banyak menghabiskan waktu bersentuhan langsung dengan tanah. Umumnya siswa SD bisa terkena cacingan karena kurang baiknya akses mendapatkan air bersih, sanitasi yang buruk, dan kebiasaan hidup bersih yang kurang diperhatikan. Keberadaan cacing parasit di dalam tubuh akan mempengaruhi gizi pada anak SD. Anak SD yang terinfeksi kecacingan akan menghambat konsentrasi menerima pelajaran di Sekolah.

\section{Intensitas cacing parasitic}

Intensitas cacing parasit terbanyak yaitu cacing Ascaris lumbricoides sebesar 227 telur cacing. Intensitas cacing $A$. lumbricoides sebesar 25,992 [19]. Keberadaan cacing tersebut sebesar 76 telur cacing [20]. Tingkat intensitas cacing $A$. lumbricoides sebesar 32,4\% [21]. Menurut WHO jumlah telur cacing A. lumbricoides sebesar 227 (83\%) tergolong sedang angka kesakitannya. Jumlah cacing yang banyak tidak menyebabkan kematian melainkan mengalami kurang nafsu makan.

\section{KESIMPULAN}

Karakteristik siswa Sekolah dasar tertinggi yaitu tidak memakai alas kaki pada saat bermain berkaitan dengan transmisi kecacingan. Distribusi cacing parasit yang menginfeksi anak SD di Kecamatan Rakumpit yaitu Ascaris lumbricoides, Toxocara sp., Taenia sp., dan Fasciolopsis sp. 
Prevalensi tertinggi yaitu $A$. Lumbricoides sebesar $69,38 \%$. Cacing A. Lumbricoides tertinggi intensitasnya sebesar $83 \%$.

\section{REFERENCES}

[1] BAPPEDA Kota Palangka Raya, Profil Kota Palangka Raya Tahun 2017. Palangka Raya: Badan Perencanaan Pembangunan Daerah Kota Palangka Raya, 2018.

[2] M. Abdi, E. Nibret, and A. Munshea, "Prevalence of intestinal helminthic infections and malnutrition among schoolchildren of the Zegie Peninsula, northwestern Ethiopia," J. Infect. Public Health, vol. 10, no. 1, pp. 84-92, 2017, doi: 10.1016/j.jiph.2016.02.009.

[3] A. Abera and E. Nibret, "Prevalence of gastrointestinal helminthic infections and associated risk factors among schoolchildren in Tilili town, northwest Ethiopia," Asian Pac. J. Trop. Med., vol. 7, no. 7, pp. 525-530, 2014, doi: 10.1016/S1995-7645(14)60088-2.

[4] D. Bisara and Mardiana, "Kasus Kecacingan Pada Murid Sekolah Dasar Di Kecamatan Mentewe, Kabupaten Tanah Bumbu Kalimantan Selatan Tahun 2010," J. Ekol. Kesehat., vol. 13, no. 3 Sep, pp. 255-264, 2016, doi: 10.22435/jek.v13i3Sep.5120.255-264.

[5] V. Y. Belizario, F. I. G. Totañes, W. U. de Leon, Y. F. Lumampao, and R. N. T. Ciro, "Soil-transmitted helminth and other intestinal parasitic infections among school children in indigenous people communities in Davao del Norte, Philippines," Acta Trop., vol. 120, no. SUPPL. 1, pp. 12-18, 2011 ,

doi:

10.1016/j.actatropica.2011.02.010

[6] J. Arthur-McKenzie and A. A. Ansari, "Short communication: The diversity of intestinal parasitic helminths in children of silvercity, linden, guyana," Biodiversitas, vol. 19, no. 4, pp. 1289-1293, 2018, doi: 10.13057/biodiv/d190415.

[7] S. Ojja et al., "Prevalence, intensity and factors associated with soil-transmitted helminths infections among preschool-age children in Hoima district, rural western Uganda," BMC Infect. Dis., vol. 18, no. 1, pp. 1-12, 2018, doi: 10.1186/s12879-0183289-0.

[8] N. H. Rosyidah and H. Prasetyo, "Prevalence of Intestinal Helminthiasis in Children at North Keputran Surabaya at 2017," J. Vocat. Heal. Stud., vol. 01, no. 01, pp. 117-120, 2018, doi: 10.20473/jvhs.

[9] U. Mahmudah, "Hubungan sanitasi lingkungan rumah terhadap kejadian infeksi kecacingan pada anak sekolah dasar," J. Kesehat., vol. 10, no. 1, pp. 3239, 2017, doi: 10.1017/CBO9781107415324.004.

[10] D. Rowardho, Sayono, and T. S. Ismail, "Keberadaan telur cacing usus pada kuku dan tinja siswa sekolah alam dan non alam," J. Kesehat. Masy. Indones., vol. 10, no. 2, pp. 18-25, 2015.

[11] P. pamela F. Sumolang and S. Chadijah, "Prevalensi Kecacingan Usus pada Anak Sekolah Dasar di Kota Palu, Sulawesi Tengah," J. Vektor Penyakit, vol. 6, no. 2, pp. 14-19, 2012, [Online]. Available: http://ejournal.litbang.depkes.go.id/index.p hp/MPK/article/view/3487.

[12] B. Hairani, D. Andiarsa, and D. Fakhrizal, "Risiko Infeksi Cacing Usus pada Anak Sekolah Dasar Berdasarkan Ekosistem yang Berbeda di Kabupaten Tanah Bumbu Tahun 2009," J. Buski, vol. 4, no. 3, p. 21435, 2013.

[13] V. P. Gyang et al., "Intestinal parasitic infections: Current status and associated risk factors among school aged children in an archetypal African urban slum in Nigeria," J. Microbiol. Immunol. Infect., vol. 52, no. 1, pp. 106-113, 2019, doi: 10.1016/j.jmii.2016.09.005.

[14] A. T. R. Amaliah and Azriful, "Distribusi spasial kasus kecacingan (Ascaris lumbricoides) terhadap personal higiene anak balita di Pulau Kodingareng Kecamatan Ujung Tanah Kota Makassar Tahun 2016," J. Epidemiol. UIN Alauddin, vol. 2, no. 2, pp. 74-80, 2016, doi: 24431141.

[15] D. Adu-Gyasi et al., "Epidemiology of soil transmitted Helminth infections in the middle-belt of Ghana, Africa," Parasite Epidemiol. Control, vol. 3, no. 3, p. e00071, 2018, doi: 10.1016/j.parepi.2018.e00071.

[16] S. Vaz Nery et al., "Risk factors for infection with soil-transmitted helminths during an integrated community level water, sanitation, and hygiene and deworming intervention in Timor-Leste," Int. J. Parasitol., vol. 49, no. 5, pp. 389-396, 2019, doi: 10.1016/j.ijpara.2018.12.006.

[17] A. G. P. Ross et al., "Risk factors for human helminthiases in rural Philippines," Int. J. Infect. Dis., vol. 54, pp. 150-155, 2017, doi: 
10.1016/j.ijid.2016.09.025.

[18] J. Pipiková, I. Papajová, J. Šoltys, and I. Schusterová, "Occurrence of the most common helminth infections among children in the Eastern Slovak Republic," Public Health, vol. 150, pp. 71-76, 2017, doi: 10.1016/j.puhe.2017.05.011.

[19] J. Bopda et al., "Prevalence and intensity of human soil transmitted helminth infections in the Akonolinga health district ( Centre Region , Cameroon ): Are adult hosts contributing in the persistence of the transmission ?," PAREPI, vol. 1, no. 2, pp. 199-204, 2016, doi: 10.1016/j.parepi.2016.03.001.

[20] M. A. Nurjana, P. P. Sumolang, S. Chadijah, and N. N. Veridiana, "Risk Factors of Ascaris Lumbricoides Infection in Elementary School Children in Palu Municipality," J. Dis. Vector, vol. VII, no. 1, pp. 23-29, 2013, [Online].Available: http://ejournal.litbang.depkes.go.id/index. php/vektorp/ article/viewFile/7495/5177.

[21] F. Fatimah, S. Sumarni, and M. Juffrie, "Derajat keparahan infeksi Soil Transmitted Helminths terhadap status gizi dan anemia pada anak sekolah dasar," J. Gizi Klin. Indones., vol. 9, no. 2, p. 80, 2012, doi: 10.22146/ijcn.15384. 